\title{
Impact of LUCC on streamflow based on the SWAT model over the Wei River basin on the Loess Plateau in China
}

\author{
Hong Wang ${ }^{1}$, Fubao Sun ${ }^{1,2,3,5}$, Jun Xia ${ }^{4,5}$, and Wenbin Liu ${ }^{1}$ \\ ${ }^{1}$ Key Laboratory of Water Cycle and Related Land Surface Processes, Institute of Geographic Sciences and Natural \\ Resources Research, Chinese Academy of Sciences, Beijing 100101, China \\ ${ }^{2}$ Research School of Qilian Mountain Ecology, Hexi University, Zhangye, Gansu Province 734000, China \\ ${ }^{3}$ College of Resources and Environment, University of Chinese Academy of Sciences, Beijing 100049, China \\ ${ }^{4}$ State Key Laboratory of Water Resources and Hydropower Engineering Sciences, Wuhan University, Wuhan 430072, China \\ ${ }^{5}$ Center for Water Resources Research, Chinese Academy of Sciences, Beijing 100101, China
}

Correspondence to: Fubao Sun (sunfb@igsnrr.ac.cn)

Received: 30 June 2016 - Discussion started: 10 August 2016

Revised: 20 March 2017 - Accepted: 21 March 2017 - Published: 6 April 2017

\begin{abstract}
Under the Grain for Green Project in China, vegetation recovery construction has been widely implemented on the Loess Plateau for the purpose of soil and water conservation. Now it is becoming controversial whether the recovery construction involving vegetation, particularly forest, is reducing the streamflow in the rivers of the Yellow River basin. In this study, we chose the Wei River, the largest branch of the Yellow River, with revegetated construction area as the study area. To do that, we apply the widely used Soil and Water Assessment Tool (SWAT) model for the upper and middle reaches of the Wei River basin. The SWAT model was forced with daily observed meteorological forcings (19602009) calibrated against daily streamflow for 1960-1969, validated for the period of 1970-1979, and used for analysis for 1980-2009. To investigate the impact of LUCC (land use and land cover change) on the streamflow, we firstly use two observed land use maps from 1980 and 2005 that are based on national land survey statistics merged with satellite observations. We found that the mean streamflow generated by using the 2005 land use map decreased in comparison with that using the 1980 one, with the same meteorological forcings. Of particular interest here is that the streamflow decreased on agricultural land but increased in forest areas. More specifically, the surface runoff, soil flow, and baseflow all decreased on agricultural land, while the soil flow and baseflow of forest areas increased. To investigate that, we then designed five scenarios: (S1) the present land use (1980) and (S2) 10\%, (S3) $20 \%$, (S4) $40 \%$, and (S5) $100 \%$ of agricultural land that
\end{abstract}

was converted into mixed forest. We found that the streamflow consistently increased with agricultural land converted into forest by about $7.4 \mathrm{~mm}$ per $10 \%$. Our modeling results suggest that forest recovery construction has a positive impact on both soil flow and baseflow by compensating for reduced surface runoff, which leads to a slight increase in the streamflow in the Wei River with the mixed landscapes on the Loess Plateau that include earth-rock mountain area.

\section{Introduction}

Since 1999, China's Grain for Green Project has greatly increased the vegetation cover (Chen et al., 2015). The total conversion area reached 29.9 million ha by 2014 (Li, 2015), and the proposals are to further return another 2.83 million ha of farmland to forest and grassland by 2020 (NDRC, 2014). The establishment of either forest or grassland on degraded cropland has been proposed as an effective approach to mitigating climate change because these types of land use can increase soil carbon stocks (Yan et al., 2012; Deng et al., 2013). The implementation of the large-scale Grain for Green Project is undoubtedly one type of geoengineering that not only mitigates climate change, but is also expected to alter the hydrological cycle (Lacombe et al., 2008, 2016).

Some researchers have urged a cessation of the Grain for Green expansion on the Loess Plateau in China and argued that the continued expansion of revegetation could cause 
more harm than good to communities and the environment (Chen et al., 2015). One important reason was that the Grain for Green Project led to an annual decline in the streamflow of the Yellow River (Chen et al., 2015; Li, 2001). Land use change can disrupt the surface water balance and the partitioning of precipitation into evapotranspiration, runoff, and groundwater flow (Sriwongsitanon and Taesombat, 2011; Foley et al., 2005; Wagner et al., 2013). Large-scale revegetation construction changes the hydrological cycle process and the distribution of water resources. There are three controversial points of view about the impact of vegetation on streamflow as a whole. Quite a few catchment studies have indicated that the annual streamflow decreased with a revegetation increase (Zhang and Hiscock, 2010; Bosch and Hewlett, 1982; VanShaar et al., 2002; Mango et al., 2011; Farley et al., 2005; Liu and Zhong, 1978) or increased with vegetation destruction (Bosch and Hewlett, 1982; Woodward et al., 2014; Hibbert, 2001). Some catchment studies indicated that the baseflow of forests was lower due to their high evapotranspiration rates (Lørup et al., 1998; Lorup and Hansen, 1997; Smith and Scott, 1992), while other studies indicated that the baseflow increased in the dry season due to higher infiltration and recharge of the subsurface storage (the "sponge-effect hypothesis") (Price, 2011; Lørup et al., 1998; Ogden et al., 2013). In contrast, other studies showed that vegetation has a positive impact on streamflow (Tobella et al., 2014; Li et al., 2001) or no impact on streamflow (Wang, 2000; Beck et al., 2013).

To interpret the controversial results, it was argued that the impact of vegetation on the annual streamflow depends on the watershed area; the relationship between them was negative in smaller watershed areas and positive in larger watershed areas (Huang et al., 2009; Zhang, 1984). Some thought it was probably the large amount of transpiration water that played the main function in the hydrological process when the watershed was smaller. Others thought that the forest areas of larger watersheds could increase precipitation and vegetation and was also conducive to the infiltration of precipitation, which increased the proportion of the underground streamflow in forest regions. Some researchers have indicated that tree planting has both negative and positive effects on water resources and that the overall effect was the result of a balance between them, which was strongly dependent on tree density (Tobella et al., 2014). Lacombe et al. (2016) found that soil infiltrability was an important factor in explaining how two modes of afforestation (natural regeneration vs. planting) led to opposite changes in the streamflow regime. Huang (1982) analyzed Soviet research results and found that $48 \%$ of runoff coefficients increased, $32 \%$ had no change, and $20 \%$ decreased with a watershed forest increase. The increased regions were located in high latitudes and humid areas. Under these conditions, the total evaporation in wooded areas and woodless areas is equal. The speculation was that snow may be blown away or to wooded areas from woodless areas, which could enhance the coefficient of the streamflow, but these factors would be weaker over low to middle latitudes than in high latitudes (Huang, 1982). Further, vegetation may change the hydrological cycle through the following (Le Maitre et al., 1999): the redirection of precipitation by the canopy; branches, stem, and litter tending to intercept more water into the soil; or roots possibly providing channels for the flow to infiltrate to the groundwater and extract soil water as evaporation. Hence, different results have led to a contentious relationship between vegetation and streamflow (Bradshaw et al., 2007; Dijk et al., 2009).

The Wei River is one main branch of the Yellow River where measures for soil and water conservation, including forestation, terraces, grass, and a check dam, have been widely implemented since the 1980s. Meanwhile, the annual streamflow of the Wei River has decreased significantly since the 1980s (Liu and Hu, 2006; Lin and Li, 2010; Wang et al., 2011). Since the 1990s, the streamflow has sharply dropped and the observed streamflow at the Linjiacun station in the 1990s was less than one-third of that before the 1990s. The terrace and the check dam both had a negative effect on the annual streamflow, which was a result of the balance between the streamflow decreasing in the flood season and the baseflow increasing in the non-flood season on the Loess Plateau (Shao et al., 2013; Xu et al., 2012). However, the impacts of vegetation on streamflow are controversial and complicated. Meanwhile, on the Loess Plateau, it was found that there is a drying layer of soil underneath the forest with a depth of 1 to $3 \mathrm{~m}$ from the soil surface owing to the serious soil desiccation in water-limited ecosystems ( $\mathrm{Li}, 2001$; Wang et al., 2010a). The land use, rainfall, soil type, and slope gradient had a significant impact on the dried soil layer thickness (Wang et al., 2010b). The large water deficit prevents the gravitational infiltration of rainfall and the replenishment of the groundwater. Forests on the Loess Plateau reduced streamflow as a result of the increased retention of rainfall and the reduced recharge into the groundwater $(\mathrm{Li}, 2001$; Tian, 2010). For the earth-rock mountain landscape, however, vegetation grows on a thinner soil layer of rocky mountain, which is apt to be saturated and produce soil flow on relatively impermeable rock. So, the streamflow in wooded areas might be larger than that in adjacent woodless areas. Under this situation, forests may have a positive impact in terms of producing streamflow (Liu and Zhong, 1978).

To investigate that, we develop hydrological experiments based on the widely used SWAT model and observed hydrological and meteorological data and land use data for the Wei River. We aim at understanding the possible impact of revegetation construction, especially forest restoration, on streamflow and its components in the Wei River, which is not only the largest branch of the Yellow River, but also has a very mixed landscape with the Loess Plateau and earth-rock mountain areas. In Sect. 2, we describe the study area and the data. In Sect. 3, we set up, calibrate, and validate the SWAT model in the Wei River. Section 4 reports the numerical ex- 


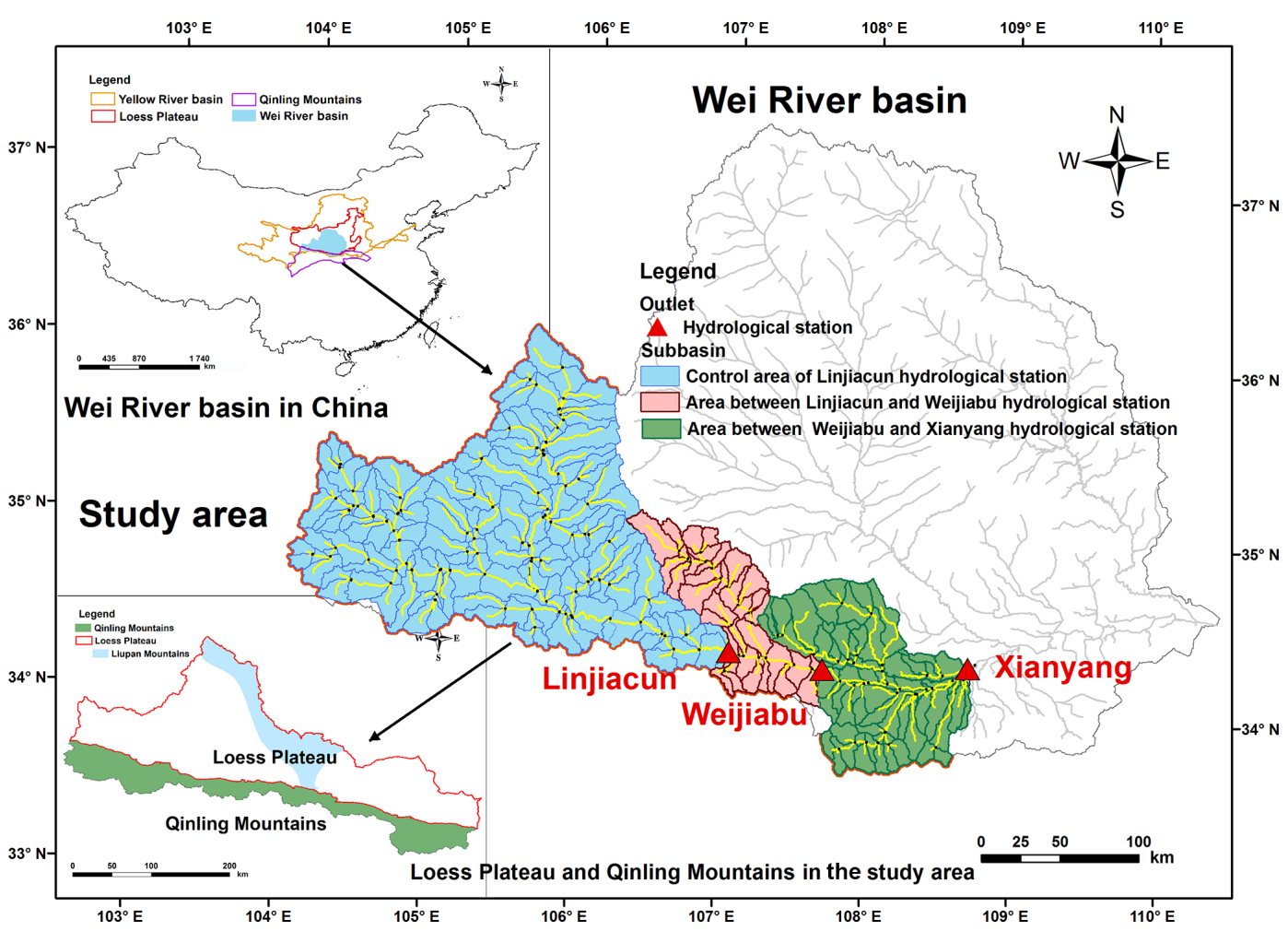

Figure 1. The study area in the Wei River basin on the Loess Plateau.

periment results, which is then followed by the conclusion in Sect. 5 .

\section{Study area and data}

\subsection{Study area}

The Wei River is the largest tributary of the Yellow River, which originates from the north of the Wushu Mountains at an altitude of $3495 \mathrm{~m}$ (involving the Gansu, Ningxia, and Shaanxi provinces) and runs across $818 \mathrm{~km}$ into the Yellow River at Tongguan County in the Shaanxi Province. In this study, we chose the upper and middle reaches $\left(4.68 \times 10^{4} \mathrm{~km}^{2}\right)$ of the Wei River basin $\left(103.97-108.75^{\circ} \mathrm{E}\right.$, $33.69-36.20^{\circ} \mathrm{N}, 13.48 \times 10^{4} \mathrm{~km}^{2}$ ), and the Linjiacun, Weijiabu, and Xianyang hydrological stations are used from upstream to midstream (Fig. 1), which divided the study area into three regions. The Linjiacun station is located at the control section of the upstream and the Xianyang station is the control station for the middle reaches.

Geologically, the basin consists of the Loess Plateau and the Qinling Mountains in the respective north and south of the Wei River (Fig. 1). In the north, there are fewer tributaries with longer lengths and the gradient is smaller. In the south, abundant tributaries originate from the Qinling Mountains, which are steep and close to the river. So, the tributaries are shorter and the flows are swifter. A lot of earth-rock moun- tain landscape and gravel riverbed is distributed in the piedmont.

\subsection{Land use and land cover change (LUCC) data}

We obtained the observed LUCC data from the National Science \& Technology Infrastructure of China, National Earth System Science Data Sharing Infrastructure (Fig. 2) (http://www.geodata.cn). Land use maps for the years 1980 and 2005 were interpreted based on the corresponding national land use survey data $(1: 100000)$, satellite images, the MODIS data, and $250 \mathrm{~m}$ space resolution data. They were combined with a pasture resources map $(1: 500000)$, soil type maps $(1: 1000,000)$, a vegetation type map (1: 1000000$)$, and other auxiliary data. The LUCC data were divided into 6 types and a further 25 subtypes. The six types included forest, shrubland, pasture, cropland, water bodies, and residential areas: (1) the forest type includes range brush (RNGB), forest mixed (FRST), forest deciduous (FRSD), pine (PINE), and forest evergreen (FRSE); (2) the pasture type includes pasture (PAST), winter pasture (WPAS), and range grasses (RNGE); (3) the cropland means agricultural land (AGRL); (4) water includes water bodes (WATR) and wetlands mixed (WETL); (5) the residential areas include areas of residential high density (URHD) and residential medium density (URMD); (6) and the code for bare land is BARE. The area of agricultural land de- 

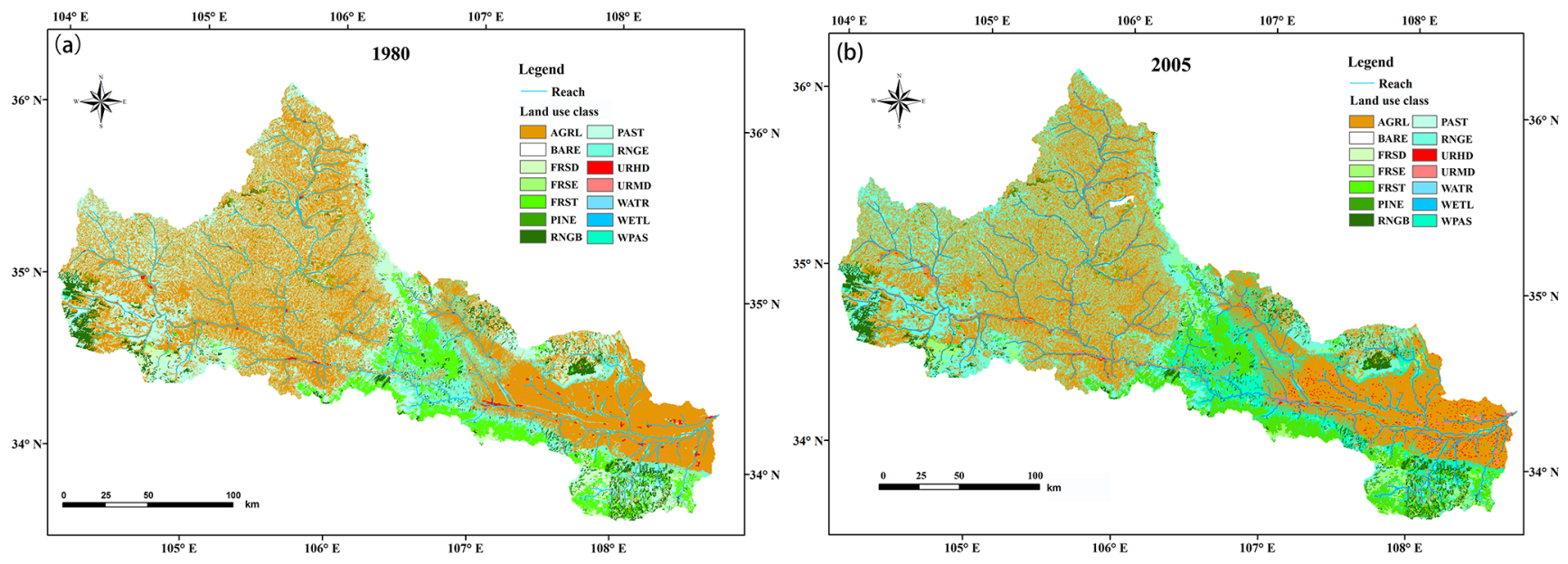

Figure 2. The observed land use data for the year 1980 and the year 2005 in the study area.
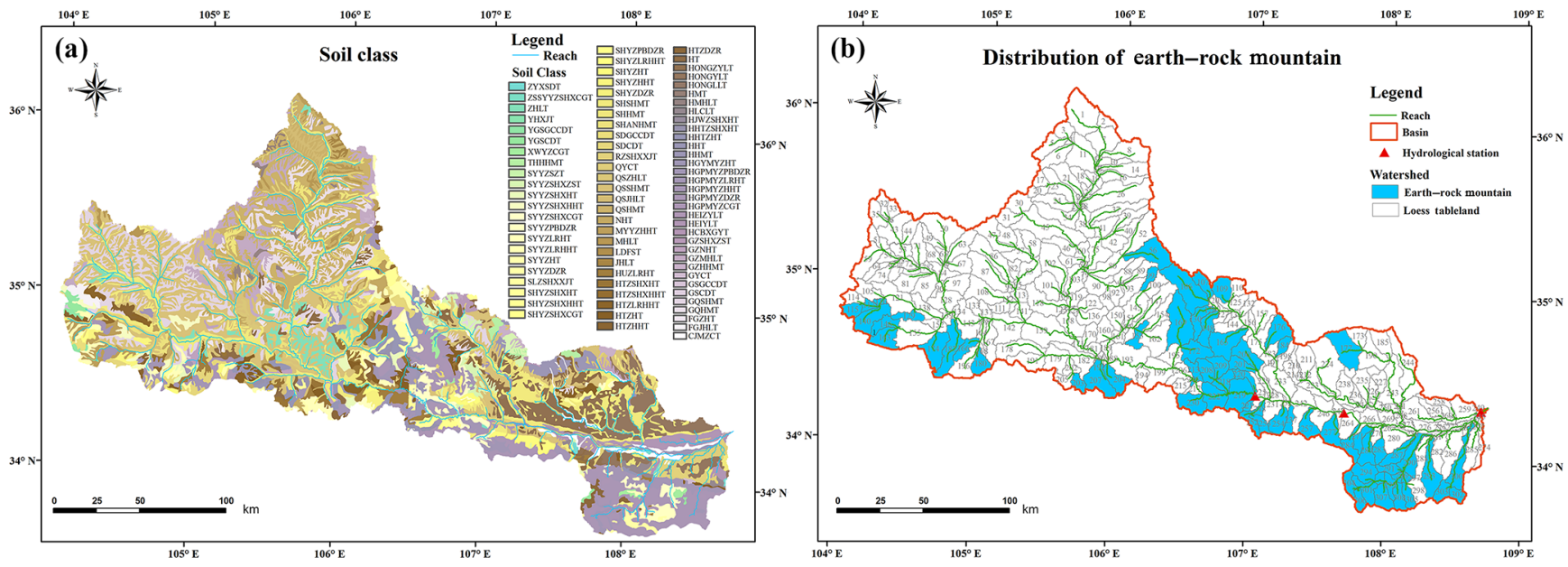

Figure 3. The soil data and the distribution of earth-rock mountains in the study area.

creased by about $7.26 \%$ and the forest area increased by $0.81 \%$ in 2005 compared with 1980 for the study area.

\subsection{Soil data}

The soil data were obtained from the National Science \& Technology Infrastructure of China, National Earth System Science Data Sharing Infrastructure (Fig. 3a) (http: //www.geodata.cn). This soil data map reflects the distribution and characteristics of the different soil types digitized based on 1:500 000 remote-sensing digital figures of the environment on the Loess Plateau.

Based on the soil data, the distribution of earth-rock mountain in the study area is shown in Fig. 3b. There were 83 soil types in the study area, and 15 of them are composed of earth and rock involving 70 hydrological response units (HRUs) (Table 1). At the same time, these 15 soil types are distributed mainly in the Qinling Mountains and the Li- upan Mountains (Fig. 1). The earth-rock mountain area accounts for $24 \%$ of the study area.

\subsection{Meteorological and hydrological data}

The meteorological data were obtained from the China Meteorological Data Sharing Service System (http://www. escience.gov.cn/metdata/page/index.html) and local rainfall stations. The data include atmospheric pressure, mean (minimum and maximum) temperature, vapor pressure, relative humidity, rainfall, wind speed, wind direction, and sunshine time. Figure 4a shows the distribution of the meteorological stations and the annual average precipitation over the Wei River basin, which was calculated using a kriging interpolation method with ArcGIS 9.3 (esri, Redlands, CA, USA) based on the annual average precipitation at 34 meteorological stations. Then, the time series of the annual average precipitation for the three regions in the study area were calculated using and elevation band method with ArcSWAT (Soil 
Table 1. The soil types and their distribution over the earth-rock mountains in the study area.

\begin{tabular}{|c|c|c|c|c|}
\hline No. & Code of soil type & Physical meaning of the code & HRU & $\begin{array}{r}\text { Area } \\
\left(\mathrm{km}^{2}\right)\end{array}$ \\
\hline 1 & SHYZHT & Limestone cinnamon soil & 220,257 & 26316.90 \\
\hline 2 & SHYZSHXHT & Limestone Calcic cinnamon soil & 153 & 11471.22 \\
\hline 3 & SYYZLRHT & Sandstone; shale Luvic cinnamon soil & $166,203,207$ & 50065.29 \\
\hline 4 & HGPMYZLRHT & Granite; gneiss Luvic cinnamon soil & $\begin{array}{l}174,180,187,201,204, \\
221,277,283,287\end{array}$ & 158397.93 \\
\hline 5 & SYYZDZR & Sandstone; shale light brown earth & $106,169,299$ & 103955.40 \\
\hline 6 & HGPMYZDZR & Granite; gneiss light brown earth & $\begin{array}{l}130,148,172,209,252, \\
284,289,290,291,293, \\
294,300,301,302,303, \\
305,306,307,308\end{array}$ & 299737.26 \\
\hline 7 & HGPMYZPBDZR & Granite; gneiss light brown earth & 253 & 8739.90 \\
\hline 8 & MYYZHHT & Sandstone; shale grey cinnamon soil & $115,117,146,163$ & 51204.96 \\
\hline 9 & SYYZSHXHHT & Sandstone; shale Calcic grey cinnamon soil & 99,129 & 19392.21 \\
\hline 10 & SHYZSHXHHT & Limestone; Calcic grey cinnamon soil & 56 & 33885.54 \\
\hline 11 & SYYZSHXZST & Sandstone; shale purple soil & $109,176,177,184,200$ & 106159.41 \\
\hline 12 & HGPMYZCGT & Granite; gneiss Regosol & $\begin{array}{l}165,230,237,254,271 \\
292,295,296,297,304\end{array}$ & 112136.40 \\
\hline 13 & SYYZSHXCGT & Sandstone; shale Regosol & $\begin{array}{l}107,208,213,216,218, \\
219,248\end{array}$ & 87612.84 \\
\hline 14 & SHYZSHXCGT & Limestone Regosol & 222 & 23375.79 \\
\hline 15 & SYYZLRHHT & Sandstone; shale Luvic grey cinnamon soil & 116,140 & 30320.73 \\
\hline
\end{tabular}

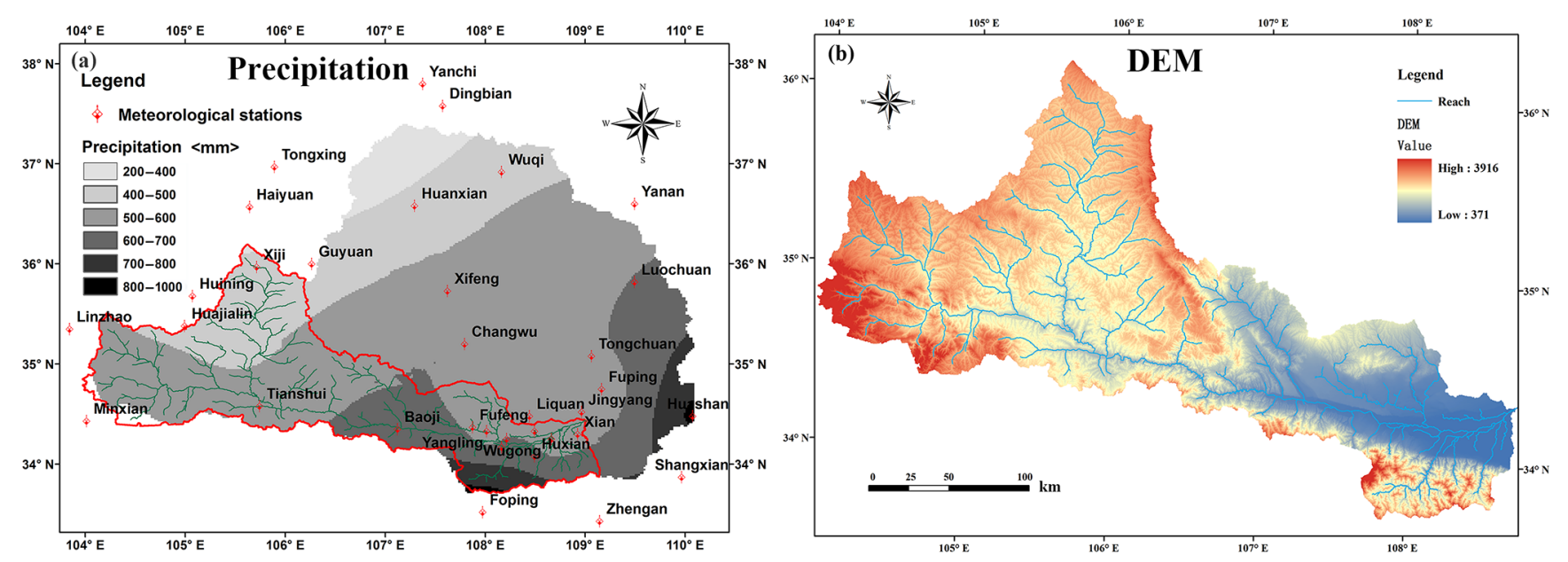

Figure 4. The spatial distribution of the annual average precipitation in the Wei River basin over the past 55 years (1956-2010) and the DEM of the study area.

and Water Assessment Tool) 2009.93.7b, which can account for orographic effects on precipitation (Neitsch et al., 2011). SWAT allows the subbasin to be split into a maximum of ten elevation bands. Precipitation is calculated for each elevation band as a function of the respective lapse rate and the difference between the gauge elevation and the average elevation specified for the band. Once the precipitation values have been calculated for each elevation band in the subbasin, the new average subbasin precipitation value is calculated based on the fraction of the subbasin area within the eleva- tion band (Neitsch et al., 2011). Figure 5b-d shows the time series of the average precipitation calculated though the elevation band method with ArcSWAT from 1960 to 2009. The average precipitation in regions $1-3$ was $489.71,493.25$, and $566.60 \mathrm{~mm} \mathrm{yr}^{-1}$ and the trend analysis showed that the precipitation decreased at an average rate of $0.57,0.55$, and $0.21 \mathrm{~mm} \mathrm{yr}^{-1}$, whereas the decreasing tendencies were not significant at the 0.05 level.

The daily streamflow data for the three hydrological stations were obtained from the Ecological Environment 


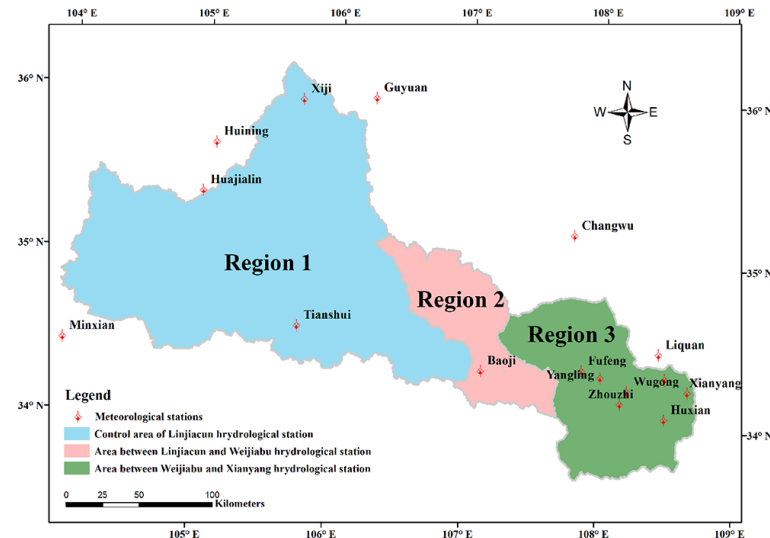

(a) Meteorological stations of three regions

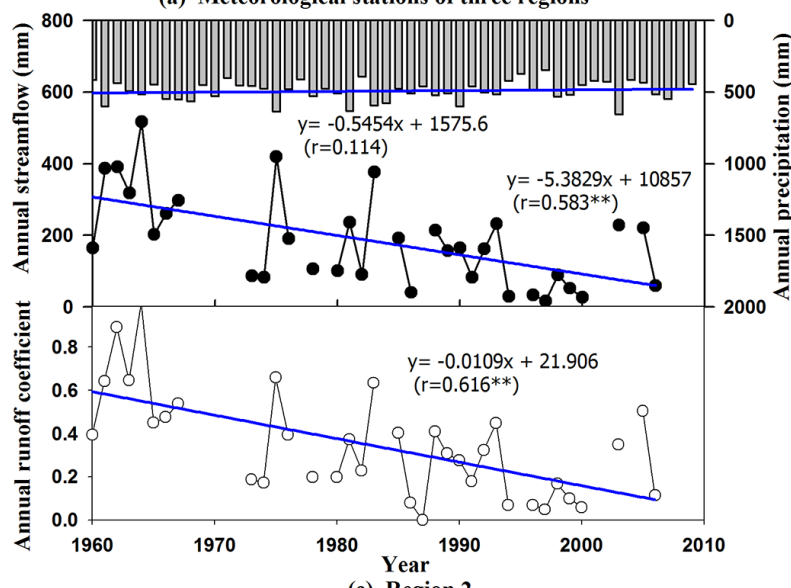

(c) Region 2

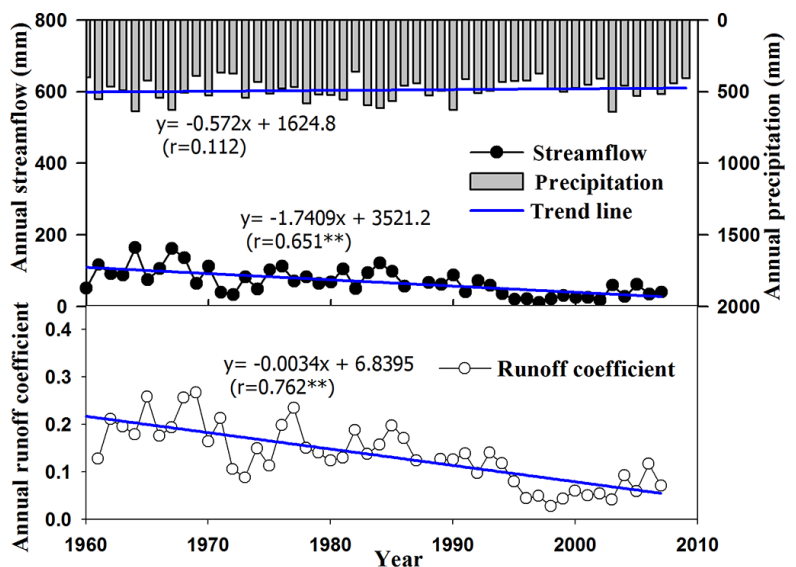

(b) Region 1

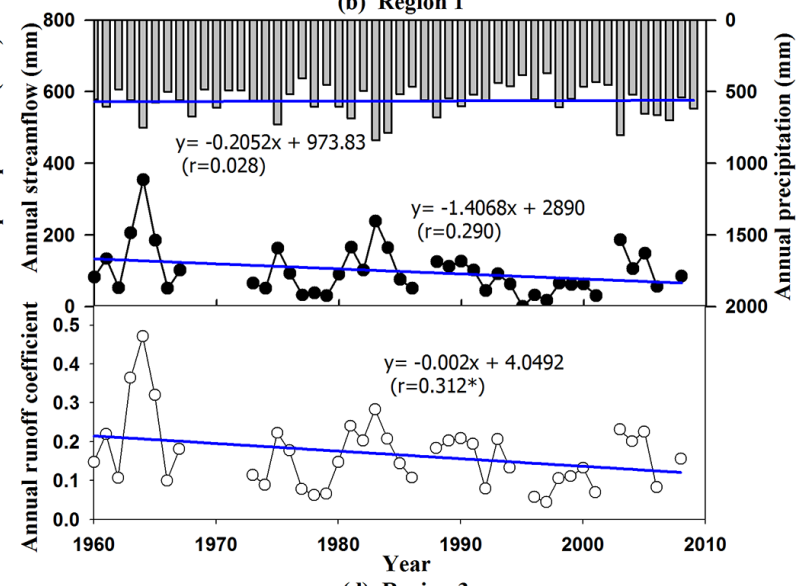

(d) Region 3

Figure 5. The time series of the precipitation, annual streamflow, and runoff coefficients for the regions in the study area.

Database of the Loess Plateau (http://www.loess.csdb.cn/ pdmp/index.action) and the Hydrological Yearbooks of China. Figure $5 \mathrm{~b}-\mathrm{d}$ shows the time series of the annual streamflow and the runoff coefficients in the three regions of the study area. The trend analysis showed that the streamflow of regions 1 and 2 decreased extremely significantly $(P<0.01)$ at an average rate of 1.74 and $5.38 \mathrm{~mm} \mathrm{yr}^{-1}$. The streamflow of region 3 did not decrease significantly. The average runoff coefficients were $0.13,0.34$, and 0.17 in regions $1-3$ over the past 50 years (1960-2009). The trend analysis of the runoff coefficients showed that the tendencies of regions 1 and 2 decreased extremely significantly $(P<0.01)$ at an average rate of 0.34 and $1.09 \%$ per year. The runoff coefficient of region 3 also decreased significantly $(P<0.01)$ at an average rate of $0.2 \%$ per year.

A $90 \mathrm{~m}$ resolution digital elevation model (DEM) (Fig. 4b) was used to define the topography characteristics (such as elevation, slope, and aspect) and delineate the watershed boundary. It was obtained from the Computer Network Information Center, Chinese Academy of Sciences (http://srtm. datamirror.csdb.cn/) based on the Shuttle Radar Topography Mission (SRTM) version 4.1.

\section{Methods}

\subsection{The SWAT model}

The SWAT model is developed by the USDA Agricultural Research Service (ARS). It is a physically based and distributed hydrological model. The SWAT model has been widely applied to understand the impact of land management practices on water, sediment, and agricultural yields over large complex watersheds with varying soils, land use, and management conditions over long periods (Arnold et al., 2009). It is forced with meteorological data, and input and includes soil properties, topography, land use, and land management practices in the catchment. The physical processes associated with hydrological cycle and sediment movement are directly modeled by SWAT using these input data (Arnold et al., 2009). In addition, the ArcSWAT extension (ArcSWAT 2009.93.7b version) is used as the graphical user interface for the SWAT model (Gassman et al., 2007; Arnold et al., 1998). Surface runoff, soil, and baseflow are considered for the streamflow. Soil flow is a streamflow contribution that originates below the surface but above the zone where rocks are saturated with water. Baseflow is the volume 
of streamflow that originates from the groundwater (Arnold et al., 1993).

\subsection{The SWAT model setup}

The SWAT model setup includes four steps: watershed delineation, hydrological response unit (HRU) analysis, input database building, and modification and model operation. Based on research on the Wei River (Shao, 2013; Wang, 2013), the extraction threshold, which is the minimum drainage area required to form the origin of a stream, of the subbasin area was $80 \mathrm{~km}^{2}$. The Linjiacun, Weijiabu, and Xianyang hydrological stations were loaded manually as subbasin outlets, and one whole watershed outlet was defined. The study area was divided into 308 subbasins (Fig. 1). The land area in a subbasin can be further divided into the HRUs, which are the basic computing elements of the SWAT model. In this study, a subbasin was subdivided into only one HRU that was characterized by the dominant land use and soil type. The daily meteorological data, including temperature, relative humidity, sunshine duration, wind speed, and rainfall, were then input and all data were written into the database building and modification to force the SWAT model.

To evaluate the performance of the model calibration and validation, we use the $R^{2}$ and NS coefficients (Nash and Sutcliffe, 1970) (Eqs. 1 and 2):

$$
\begin{aligned}
R^{2}= & \frac{\left[\sum_{i=1}^{n}\left(o_{i}^{\mathrm{obs}}-\overline{o_{i}^{\mathrm{obs}}}\right)\left(o_{i}^{\mathrm{sim}}-\overline{o_{i}^{\mathrm{sim}}}\right)\right]^{2}}{\sum_{i=1}^{n}\left(o_{i}^{\mathrm{obs}}-\overline{o_{i}^{\mathrm{obs}}}\right)^{2}\left(o_{i}^{\mathrm{sim}}-\overline{o_{i}^{\mathrm{sim}}}\right)^{2}} \\
\mathrm{NS} & =1-\frac{\sum_{i=1}^{n}\left(o_{i}^{\mathrm{obs}}-o_{i}^{\mathrm{sim}}\right)^{2}}{\sum_{i=1}^{n}\left(o_{i}^{\mathrm{obs}}-\overline{o_{i}^{\mathrm{obs}}}\right)^{2}}
\end{aligned}
$$

where $n$ is the number of observations, $O^{\text {obs }}$ is the observed value, $O^{\text {sim }}$ is the simulated value, and the overbar means the average of the variable. $R^{2}$ describes the proportion of the variance in the measured data explained by the model; typically, 0.5 is considered an acceptable threshold (Van Liew and Garbrecht, 2003). The SWAT model simulation can be judged as "satisfactory" if the NS $>0.50$ for a monthly time step simulation. The performance rating of the SWAT model was very good when the NS $>0.75$, and the model performed well when the NS $>0.65$ (Moriasi et al., 2007).

\subsection{Calibration and validation of the SWAT model}

We set up the SWAT-CUP procedure for the sensitivity analysis, calibration, and validation in our study (Abbaspour, 2007). The sensitivity analysis is carried out by keeping all parameters constant to realistic values, while varying each parameter within the range assigned in step one. The sensitivity parameters were calibrated using the LH-OAT (Latinhypercube one-factor-at-a-time) method with a sequential uncertainty fitting (SUFI-2) program (Abbaspour, 2007; Xu et al., 2012). The $t$ stat and $p$ value were used to evaluate the sensitivity of the parameters. The $t$ stat is the coefficient of a parameter divided by its standard error, and the larger values are more sensitive. The $p$ value determines the significance of the sensitivity and a value close to zero means more significance. The most sensitive (seven) parameters were selected by the SWAT-CUP module. Combined with previous research in the Wei River, two additional parameters (SOL_K and GW_DELAY) were selected in this study (Table 2).

The initial value and the range of relevant parameters were derived from previous research in the study area (Wang, 2014; Shao, 2013; Zuo et al., 2015). Vegetation construction changes the underlying surface and affects the quantity of surface runoff and the recharge of both the soil and the groundwater. It has a significant impact on infiltration by providing a canopy and litter cover to protect the soil surface from raindrop impacts and producing organic matter that can bind soil particles and increase soil porosity (Le Maitre et al., 1999). These vegetation impacts on the hydrological process are captured and reflected by $\mathrm{CN}$ and management operation in the SWAT model. The Soil Conservation Service (SCS) curve number equation is the model for computing the amounts of streamflow in the SWAT model. Its comprehensive parameter is $\mathrm{CN}$, which relates to the soil permeability, land use, and antecedent soil water conditions. We have done some research on the impacts of LUCC on runoff, infiltration, and groundwater under different soil, slope, and rainfall intensities in the Wei River basin based on previous simulated rainfall experiments (Wang, 2014). Based on the experiments, the SCS model and the three-dimensional finite-difference groundwater flow model (MODFLOW) were calibrated and also applied. The values of the parameters related to runoff, infiltration, and groundwater, such as the initial $\mathrm{CN}$ values, the recharge rates for different LUCC, and the specific yield of the soil layer, were obtained based on experiments and mathematical simulations (Wang, 2014). Meanwhile, in the SWAT model, agricultural land and forest areas have different heat units required for plant maturity and different management operations. The agricultural land includes planting, harvesting, and auto-fertilizer operations; the forest only has plant operations. The management operation of the forest involves the leaf area index (LAT_INIT), plant biomass (BIO_INIT), and the age of the trees (CURYR_MAT).

The revegetation was mainly implemented in the study area after the 1980s. Hence, we chose 1960-1969 and 19701979 for the model calibration and validation, respectively, and used the daily streamflow data from the Linjiacun, Weijiabu, and Xianyang hydrological stations from the upper to the middle reaches (the data for 1965 and 1968-1971 are missing at the Weijiabu station). The parameters were cali- 
Table 2. The calibrated values of the model parameters.

\begin{tabular}{|c|c|c|c|c|c|}
\hline \multirow[t]{2}{*}{ Parameters } & \multirow[t]{2}{*}{ Physical meaning } & \multirow{2}{*}{$\begin{array}{r}\text { Calibration } \\
\text { range }\end{array}$} & \multicolumn{3}{|c|}{ Calibration result } \\
\hline & & & Linjiacun & Weijiabu & Xianyang \\
\hline $\mathrm{r} \_\mathrm{CN} 2$ & $\begin{array}{l}\text { Initial SCS runoff curve number for } \\
\text { moisture condition II }\end{array}$ & $-0.3-0.3$ & -0.27 & 0.05 & -0.17 \\
\hline r_SOL_AWC & Available water capacity of soil layer & $-0.6-0.6$ & 0.01 & -0.01 & -0.01 \\
\hline r_SOL_K & $\begin{array}{l}\text { Saturated hydraulic conductivity of soil } \\
\text { layer }\left(\mathrm{mm} \mathrm{h}^{-1}\right)\end{array}$ & $-0.5-0.5$ & 0.5 & 0.3 & 0.5 \\
\hline r_HRU_SLP & Average slope steepness $\left(\mathrm{m} \mathrm{m}^{-1}\right)$ & $-0.5-1.5$ & 1.5 & 0.41 & 0.52 \\
\hline r_SLSUBBSN & Average slope length (m) & $-0.5-1.5$ & 1.17 & 0.70 & 1.20 \\
\hline v_ALPHA_BF & Baseflow alpha factor & $0-1.0$ & 0.48 & 0.61 & 0.61 \\
\hline v_GW_DELAY & Groundwater delay (days) & $0-500$ & 220 & 38 & 62 \\
\hline $\mathrm{v} \_$ESCO & Soil evaporation compensation factor & $0-1.0$ & 0.65 & 0.90 & 0.80 \\
\hline $\mathrm{v} \_\mathrm{CH}$-K2 & $\begin{array}{l}\text { Effective hydraulic conductivity in main } \\
\text { channel alluvium }\end{array}$ & $0-130$ & 5 & 30 & 30 \\
\hline
\end{tabular}

Notes: $v_{\text {_ }}$ means that the existing parameter value is to be replaced by the given value; $\mathrm{r}$ _ means that the existing parameter value is multiplied by $(1+$ a given value $)$.

brated for the hydrological stations from upstream to midstream using the daily streamflow of 1960-1969. Firstly, the parameters against the streamflow at the Linjiacun control station were calibrated. Secondly, based on the premise of the calibrated parameter values for the Linjiacun station, the parameters were calibrated for the subbasin controlled by the Weijiabu station. In that way, the parameters for the subbasin controlled by the Xianyang station were then calibrated. Then, the SWAT model was validated for the three hydrological stations against the streamflow from 1970 to 1979 (Fig. 6).

\section{Results and discussions}

The corresponding statistical results for the three hydrological stations showed that the ranges of NS and $R^{2}$ were 0.59 0.66 and $0.63-0.68$, respectively, in the calibration period for a daily time step. They were $0.57-0.62$ and $0.61-0.65$, respectively, in the validation period. At a monthly time step, the results of the NS and $R^{2}$ were $0.82-0.84$ and $0.79-0.86$, respectively, in the calibration period. They were $0.70-0.76$ and $0.74-0.79$, respectively, in the validation period, demonstrating the good performance of the model. In addition, the time series and the patterns of the simulated and observed streamflow during the calibration and validation periods showed similar trends (Fig. 6). Our conclusion is that the SWAT model can be used in the upper and middle reaches of the Wei River basin.

\subsection{Impact of the observed LUCC on streamflow}

The analysis above (Fig. 5) showed that the observed precipitation in the study area did not decrease significantly from 1960 to 2009, while the annual streamflow (except region 3 ) and the runoff coefficients decreased significantly
$(P<0.05)$ under this meteorological condition. This discrepancy could be attributed mostly to LUCC (Lacombe et al., 2008, 2016). In order to analyze the impact of LUCC on the streamflow, the land use data for 1980 and 2005 were used in the validated SWAT model and the DEM, and the soil data remained constant. Firstly, the daily streamflow from 1980 to 2009 was simulated using the observed daily meteorological forcing data and the topography and soil data in the study area. Secondly, the LUCC data for 1980 were replaced by those for 2005 and their relevant parameters of the corresponding land use type were also replaced. We used the LUCC data for 2005 but the same meteorological data to simulate the daily streamflow from 1980 to 2009 .

The change in the annual streamflow based on the LUCC data for 2005 compared with the LUCC data for 1980 showed that the annual streamflow at the Xianyang hydrological station decreased over 20 years in a 30-year period (1980-2009) and the annual average reduction was $2.0 \mathrm{~mm} \mathrm{yr}^{-1}$ for these 20 years in the study area. This result was consistent with the decreasing tendencies of the observed streamflow at the Xianyang station, which decreased significantly $(P<0.05)$ at an average rate of $2.45 \mathrm{~mm} \mathrm{yr}^{-1}$ from 1980 to 2009. The modeled streamflow represents the impacts of constant LUCC data for 1980 and 2005, whereas the observations are based on dynamic LUCC data, which could explain the discrepancy. Yin et al. (2017) studied the impact of LUCC on the streamflow in the Jinghe River basin, which is the largest tributary of the Wei River basin, and found that the streamflow was increasingly influenced by LUCC; it contributed to $44 \%$ of the streamflow changes between the 1980s and the 1990s and $71 \%$ of the streamflow changes between the 1990s and the 2000s. At the same time, different land use types hydrologically respond differently, even to the same meteorological forcings; i.e., rainfall intensity was of great importance in influencing the hydrological 

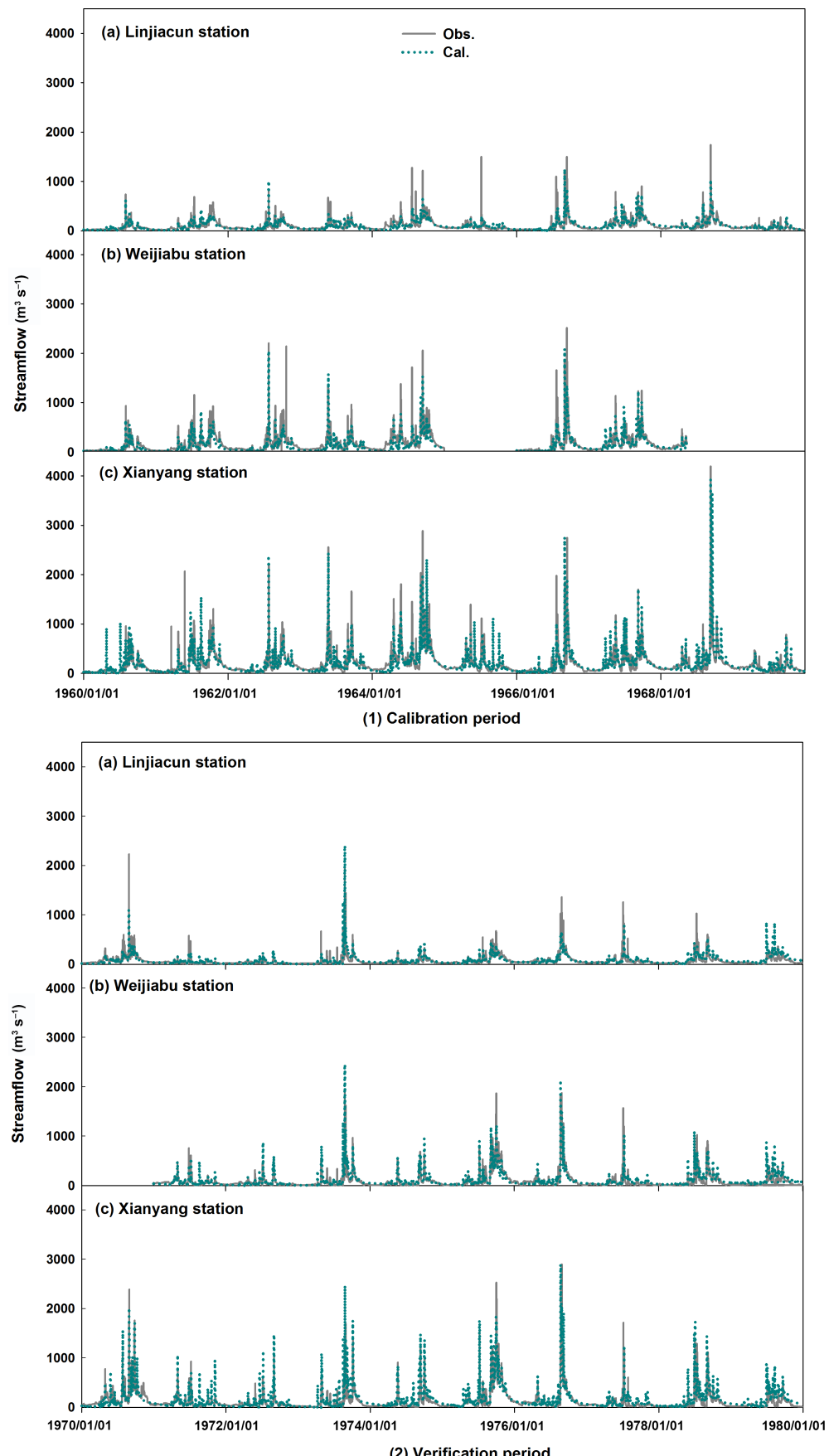

Figure 6. The time series graphs of the calculated vs. the observed values during the calibration period and the verification period for the hydrological stations.

process in semi-dry and semi-humid regions (Lacombe et al., 2008; Wang, 2014). The results of the rainfall experiments showed that when the rainfall intensity was smaller or larger, the rainfall would infiltrate into the soil or flow away as surface runoff, mainly on both grassland and bare slope, while when the rainfall intensity was medium, the rainfall would infiltrate into the grassland and flow away as surface runoff on bare slopes (Tobella et al., 2014; Wang, 2014). To reduce the influence of meteorological conditions and isolate the impact of LUCC on the streamflow, the 30-year (1980-2009) values of the streamflow for forest area and agricultural land were averaged. For the period 1980-2009, we used the measured and long-term daily meteorological data in the study area to drive the validated model for the designed hydrological experiments. Figure 7 shows the changes in the streamflow, surface runoff, soil flow, and baseflow between agri- 
Table 3. The scenarios for simulation.

\begin{tabular}{llrc}
\hline Scenario & Description & $\begin{array}{r}\text { Area } \\
\left(\mathrm{km}^{2}\right)\end{array}$ & $\begin{array}{r}\text { The average simulated } \\
\text { streamflow (1980-2009) } \\
\left(10^{8} \mathrm{~m}^{3} \mathrm{yr}^{-1}\right)\end{array}$ \\
\hline S1 & Present situation & 0 & 50.44 \\
S2 & $10 \%$ agricultural land $\rightarrow$ forest & 2937.63 & 53.92 \\
S3 & $20 \%$ agricultural land $\rightarrow$ forest & 5875.26 & 56.83 \\
S4 & $40 \%$ agricultural land $\rightarrow$ forest & 11750.53 & 62.73 \\
S5 & $100 \%$ agricultural land $\rightarrow$ forest & 29376.32 & 82.28 \\
\hline
\end{tabular}

Notes: (1) Agricultural land refers to land for crop planting, including cultivated land, newly cultivated soil, fallow fields, rotation plots, pasture-crop rotation, and land used for agro-fruit, agro-mulberry, or agroforestry (the code in the model is AGRL). (2) Forest refers to natural forests and plantations with a canopy density larger than $30 \%$, including timberland, economic forest, and protection forest (the code in the model is FRST).

cultural land and forest area. The surface runoff, soil flow, and baseflow all decreased for agricultural land, while the soil flow and baseflow of the forest area increased. Overall, the streamflow decreased on agricultural land and increased in forest areas. When the LUCC data are classified and reclassified in the SWAT model, the tree types are summarized as range brush (RNGB), forest mixed (FRST), and forest deciduous (FRSD). The different types have different hydrological responses for their leaves, roots, and so on. We also further analyzed the streamflow generation of the main types of forest (RNGB, FRST, and FRSD) in study area. The results showed that the streamflow yield of FRST and FRSD were about 1.20 and 1.60 times of that of RNGB, respectively.

\subsection{Hydrological experiments on the impact of conversion of agricultural land to forests on streamflow}

Because the LUCC data involve various land use interconversions, of particular interest here is that the impact of the conversion of cropland to forest on streamflow cannot be distinguished. Starting from the LUCC data for 1980 as (S1) the present land use, we design another four scenarios (Table 3) in which (S2) $10 \%$, (S3) $20 \%$, (S4) $40 \%$, and (S5) $100 \%$ of the agricultural land was converted into forest mixed (FRST). All experiments are carried out based on the same the DEM, soil data, and meteorological conditions.

Based on the five scenarios, the SWAT simulations were conducted to analyze the effect of forest construction on the streamflow in the upper and middle reaches of the Wei River basin. Firstly, the converted agricultural land area was controlled proportionately the as same as the variational area ratios in the three regions divided by the Linjiacun, Weijiabu, and Xianyang hydrological stations (Fig. 5a). Secondly, the lands with the same soil type and a similar slope were the priorities to choose as the converted land. Thirdly, the converted lands were distributed evenly as much as possible in the three regions. The simulation period was from 1980 to 2009 .

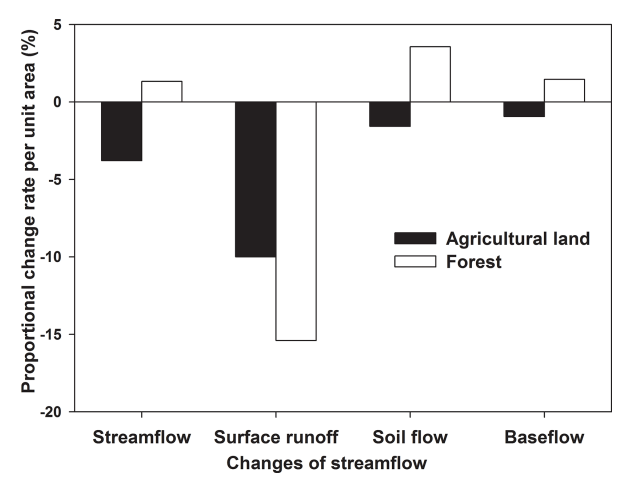

Figure 7. The changes in the 30-year (1980-2009) averages of streamflow, surface runoff, soil flow, and baseflow between agricultural land and forest.

We present the distribution of the average streamflow change under the S2-S5 scenarios compared with the S1 scenario in Fig. 8. It shows that the streamflow generally increased when the land was converted from agricultural land into forest area in the upstream. Figure 9 shows the change rate in the streamflow at the Linjiacun, Weijiabu, and $\mathrm{Xi}$ anyang stations for the annual average and the annual average over the non-flood season (January-June and NovemberDecember). Compared with the S1 scenario, the annual average streamflow increases in the non-flood season were 12.70, 11.21 , and $9.11 \%$ for the Linjiacun, Weijiabu, and Xianyang stations per $10 \%$ area of agricultural land converted into forest. Interestingly, the average annual streamflow increases were $11.61,21.63,42.51$, and $109.25 \%$ for the S2-S5 scenarios, respectively (Fig. 9b), which almost consistently suggested about $1.1 \%$ per $1 \%$ change in the agricultural land. The results are important in that a $0.8 \%$ increase in forest in the observed LUCC would lead to a less than $1 \%$ change in the streamflow, which is negligible.

To be more comparable, Fig. 10 shows the distribution of the annual runoff coefficients with the scenario changed from S1 to S5. The spatial variability in the mean runoff coefficient was large, ranging from 0.03 to 0.68 , and in- 

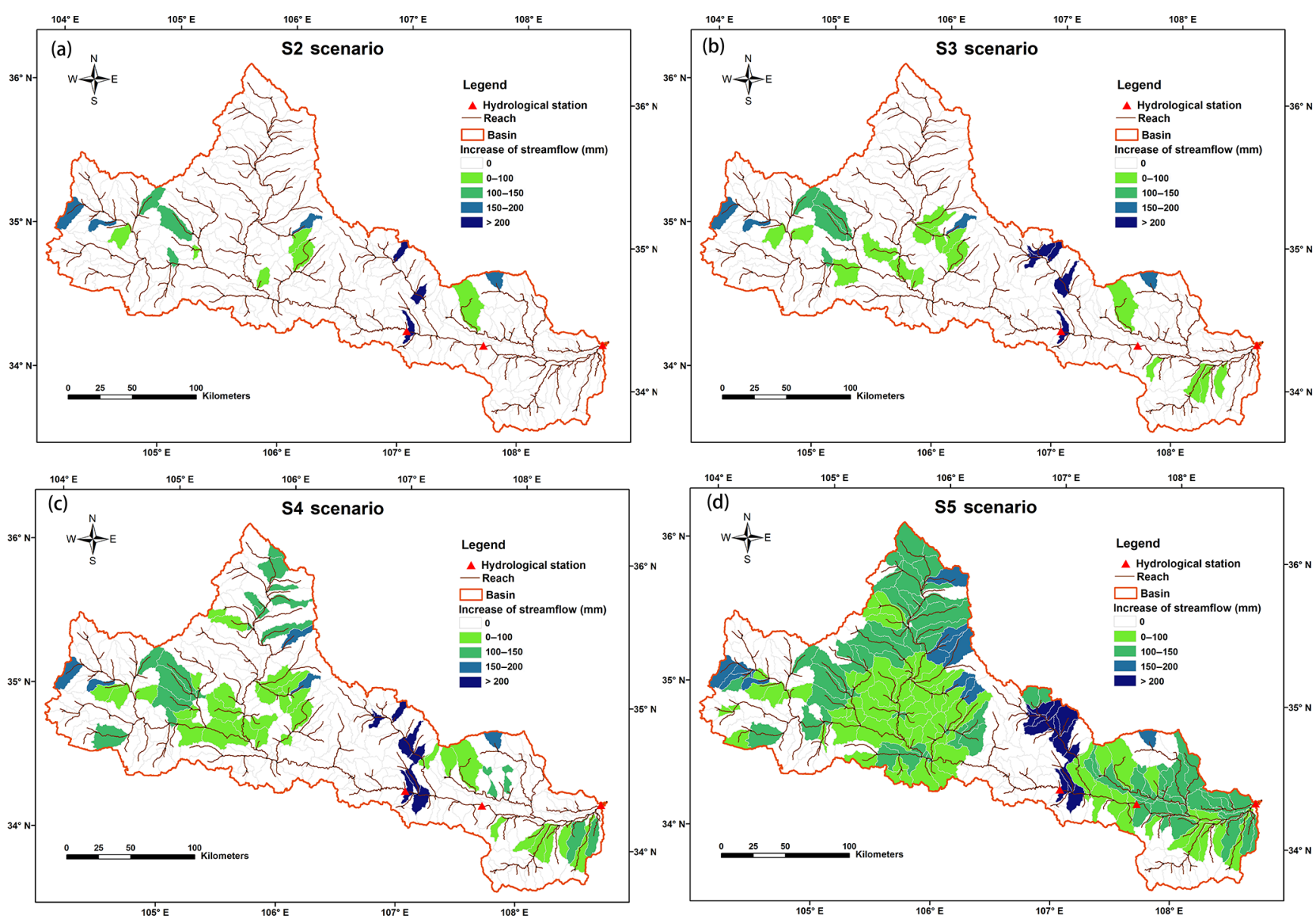

Figure 8. The watershed distribution of the average streamflow change under the S2-S5 scenarios compared with the S1 scenario.

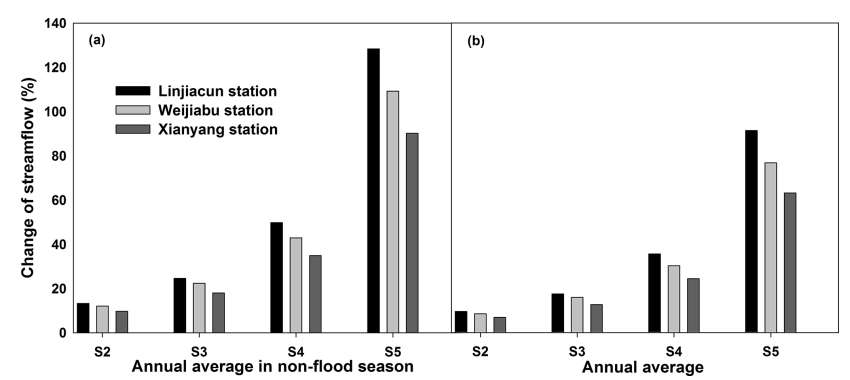

Figure 9. The corresponding proportional change rate in the streamflow at Linjiacun, Weijiabu, and Xianyang stations for the annual average and the annual average in the non-flood season.

creased with more forest area converted from agricultural land. The annual average runoff coefficient of the study area increased from 0.21 to 0.37 with forest area increasing from S1 to S5 (Fig. 11). On average, the runoff coefficient increased about 0.014 (i.e., $1.4 \%$ of rainfall transformed into streamflow) per $10 \%$ of agricultural land converted into forest area.
The landscape of the Wei River is mixed with the Loess Plateau and earth-rock mountain landscapes, which induce different mechanisms of transforming rainfall into streamflow. The earth-rock mountain area accounts for $24.03 \%$ of the study area (Fig. 3b). In the earth-rock mountain area, vegetation grows on a much thinner soil layer over the earthrock mountain. The soil has a high infiltration ability for such a high stone fragment content. The thin soil is apt to be saturated and produce more soil flow on relatively impermeable rock; hence, the streamflow in wooded areas is larger than that in adjacent woodless areas favoring streamflow production (Liu and Zhong, 1978). In contrast, on the Loess Plateau, there is a drying layer of soil underneath the forestland with a large water deficit. When the agricultural land is converted into forest, the precipitation is intercepted by vegetation, infiltrated into the soil, and supplied to the drying layer of soil for vegetation growth. Together with the much thicker soil layer on the Loess Plateau, it usually prevents gravitational infiltration into the groundwater and reduces the streamflow recharge (Li, 2001; Tian, 2010). The observed results for precipitation and streamflow in the study area also showed that the runoff coefficients had a positive correlation with the 

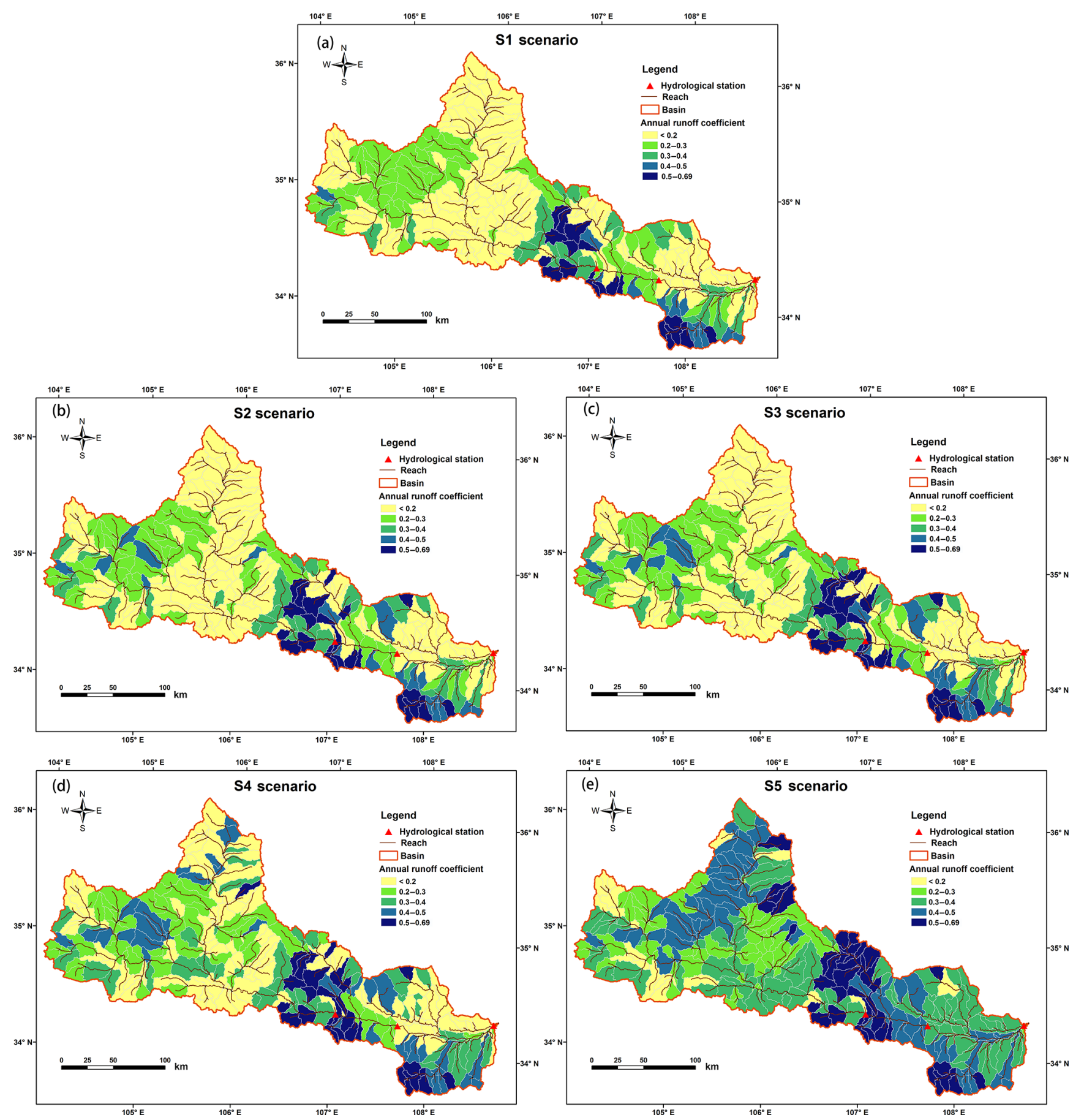

Figure 10. The distribution of the annual runoff coefficient with the scenario changed from S1 to S5.

rates of the earth-rock mountain area. The regional annual averages of the runoff coefficient were $0.13,0.17$, and 0.34 for Fig. 5b-d, while the rates for the earth-rock mountain area were opposite (Fig. 3b). The complication is that the overall effect of forest on the streamflow is in fact a balance between the earth-rock mountain positive and the Loess Plateau negative effects on the streamflow.
Combined with the spatial distribution of precipitation (Fig. 4a), we can see that the earth-rock mountain landscapes are mainly distributed in regions with more rainfall. To be precise, the whole earth-rock mountain area is located where rainfall was greater than $500 \mathrm{~mm} \mathrm{yr}^{-1}$. Over $62 \%$ of the study area where the annual rainfall is greater than $600 \mathrm{~mm}$ was earth-rock mountain area. Meanwhile, the river network 


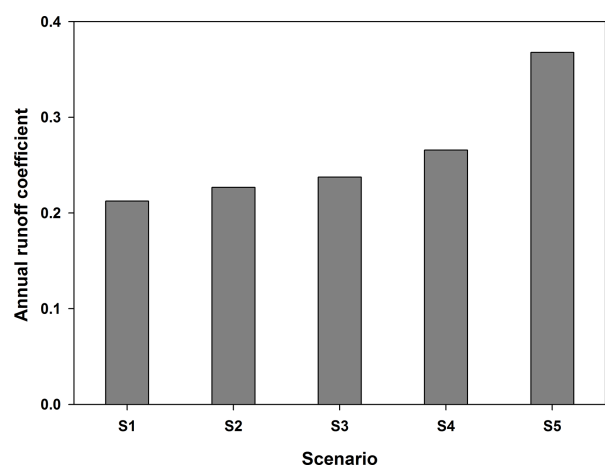

Figure 11. The annual average runoff coefficient of the study area with forest area increasing from S1 to S5.

over the earth-rock mountain area is denser, and most of the tributaries in the earth-rock mountain area are close to the main stream of the Wei River. A lot of developed gravel riverbed is also distributed in the piedmont and the sandy soil along the river and its groundwater level is shallow, which facilitates rainfall infiltration and the recharging of the streamflow. Although the area of the earth-rock mountain accounts for $24 \%$ of the study area, its distribution is concentrated in the main regions of the streamflow yield in the study area. Therefore, the overall result of the balance among all factors was that forest construction has a small positive effect on the streamflow in the study area.

This result was seemingly not consistent with the significant decreasing tendencies of the streamflow in the study area. The combined effects of LUCC, including forestation, terraces, grass, and dams, could explain the discrepancy. Under the same meteorological conditions, the streamflow is mainly a result of the combined effects of these measures. The results showed that the terrace in the main Wei River basin could delay the flood and add a drought season streamflow, which reduces the annual streamflow in general. The terrace in 2000 decreased the annual water by about 37 million $\mathrm{m}^{3}$ and increased the streamflow in the driest month by $3.5 \%$ at Xianyang station (Shao, 2013). Zhang et al. (2014) and Zhang (2014) studied the terrace measures in the Yanhe River basin, a typical basin of the Loess Plateau, and the results showed that the terrace measures could reduce the runoff in the flood season and increase the baseflow. The results also showed that $1 \mathrm{~m}^{3}$ of water could be supplied to the river when $5-6 \mathrm{~m}^{3}$ of water was stored by the terrace. This meant that the water reducing effect of the terrace was larger than $80 \%$ in the Yanhe River basin. Xu et al. (2012) applied the SWAT model to simulate the streamflow in the Yanhe basin, and the results showed that the check dams had a regulation effect on streamflow. From 1984 to 1987, the streamflow in the rainy season (from May to October) decreased by $1.54 \mathrm{~m}^{3} \mathrm{~s}^{-1}(14.7 \%)$ to $3.13 \mathrm{~m}^{3} \mathrm{~s}^{-1}(25.9 \%)$ due to the check dams; in the dry season (from November to the following April), the streamflow increased by $1.46 \mathrm{~m}^{3} \mathrm{~s}^{-1}$
(60.5\%) to $1.95 \mathrm{~m}^{3} \mathrm{~s}^{-1}(101.2 \%)$. From 2006 to 2008 , the streamflow in the rainy season decreased by $0.79 \mathrm{~m}^{3} \mathrm{~s}^{-1}$ $(15.5 \%)$ to $1.75 \mathrm{~m}^{3} \mathrm{~s}^{-1}(28.9 \%)$, and the streamflow in the dry season increased by $0.51 \mathrm{~m}^{3} \mathrm{~s}^{-1}(20.1 \%)$ to $0.97 \mathrm{~m}^{3} \mathrm{~s}^{-1}$ $(46.4 \%)$. Numerous results showed that the terrace and the check dam both had a negative effect on the annual streamflow, which was a result of the balance between the streamflow reduction in the flood season and the baseflow increase in the non-flood season on the Loess Plateau (Shao et al., 2012, 2013; Shao, 2013; Zhang, et al., 2014; Zhang, 2014; $\mathrm{Xu}$ et al., 2012). The observed streamflow was a result of the balance among forestation, terraces, grass, and dams.

\subsection{Impact of conversion of agricultural land to forests on baseflow}

In Fig. 9a, one important point is that the average increase in the non-flood season was about 1.41 times larger than the annual increase in the streamflow. To understand that, Fig. 12 shows the distribution of the baseflow index, i.e., the ratio between the baseflow and the streamflow, under the S1-S5 scenarios. We can see that the baseflow index also increased with land converted from agricultural land into forest area, which means that the groundwater contribution to the streamflow increased with the overall increase in forest area. Putting the pictures together, Fig. 13 shows the changes in the streamflow and the baseflow under the S2-S5 scenarios minus the results under the $\mathrm{S} 1$ scenario in the non-flood season. The average increases in the streamflow and baseflow were 1.14 and $0.98 \mathrm{~mm} \mathrm{yr}^{-1}$ per $1 \%$ increase in forest area, respectively. For the non-flood season, they were 0.60 and $0.53 \mathrm{~mm} \mathrm{yr}^{-1}$. The increase in the streamflow contributed by the increased baseflow was about $88.33 \%$ in the non-flood season, so the increasing streamflow was mainly contributed by groundwater with an overall increase in forest area.

Although some researchers have urged a cessation of the Grain for Green expansion on the Loess Plateau in China because it leads to an annual decline in the streamflow of the Yellow River (Chen et al., 2015; Li, 2001), our modeling results suggest that forest recovery construction has a small positive impact on both soil flow and baseflow by compensating for reduced surface runoff, which leads to a slight increase in the streamflow in the Wei River with the mixed landscapes on the Loess Plateau that include earthrock mountain areas. The rainfall patter also has a large effect on streamflow, particularly extreme rainfall. Lacombe et al. (2008) found no streamflow change when the precipitation was larger than $40 \mathrm{~mm}$. The results showed that the daily precipitation extremes seem to be consistent with a $7 \%$ increase per degree of warming (Allen and Ingram, 2002; Pall et al., 2007), and $1 \mathrm{hr}$ precipitation extremes increase twice as fast with rising temperatures as expected when daily mean temperatures exceed $12{ }^{\circ} \mathrm{C}$ (Lenderink and Meijgaard, 2008; Westra et al., 2014). The streamflow is the combined effects of LUCC (forestation, terraces, grass, dams, and so on) and 


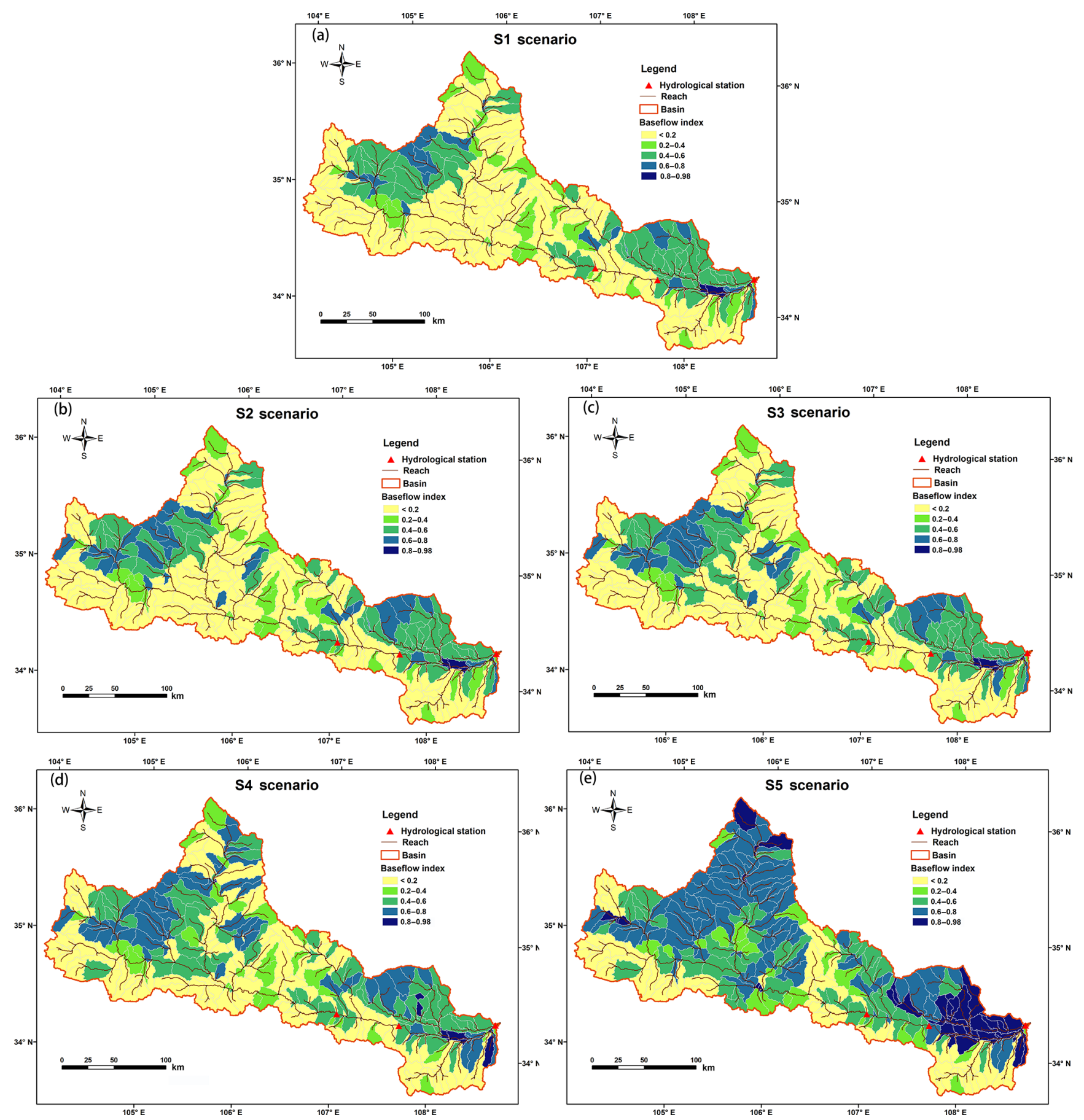

Figure 12. The distribution of the baseflow index under the S1-S5 scenarios.

climate changes. The impact of the Grain for Green Project on streamflow should be thoughtfully studied according to the characteristics of the basin.

At the same time, there are some uncertainties in the SWAT model simulations. First, the SWAT model offers comprehensive parameters for subbasins and detailed parameters for different HRUs according to their slopes, soil types, and LUCC. The comprehensive parameters were calibrated according to the observed streamflow of the subbasin, but the different parameters for the HRUs could not be calibrated individually. Second, the model could not differentiate the impact of short-duration rainfall on streamflow, which is a large effect. In addition, watershed size, generalization, and data accuracy can all lead to uncertainty in the simulations (Yin 


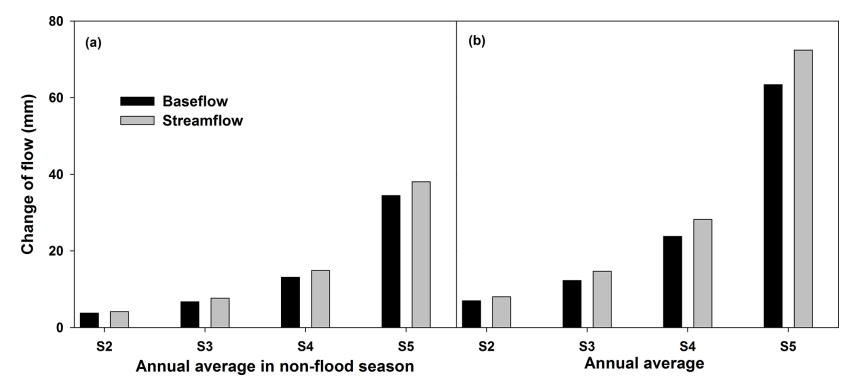

Figure 13. The corresponding change in streamflow and baseflow under the S2-S5 scenarios compared with S1 for the annual average and the non-flood season.

et al., 2017). To reduce the uncertainty in the simulation influence, the 30-year (1980-2009) values for the streamflow were averaged to analyze the impacts.

\section{Conclusion}

The large-scale implementation of the Grain for Green Project in China is expected to alter the hydrological cycle, in particular on the Loess Plateau, within the Yellow River basin. The scientific question is how large the impact of LUCC will be on the streamflow and its components in that area. We chose the Wei River as the study area because revegetation construction has been widely implemented since the 1980s. Of particular interest here is that the landscape of the upper and middle reaches of the Wei River basin is mixed, with the Loess Plateau and rocky mountain, which induces different mechanisms of generating surface runoff, soil flow, baseflow, and therefore streamflow.

To investigate, we set up the SWAT model for the upper and middle reaches of the Wei River basin with the inputs of long-term observed meteorological forcing data, hydrological data, and observed land use data. We use the daily and monthly streamflow at the Linjiacun, Weijiabu, and Xianyang hydrological stations from the upper to middle reaches during 1960-1969 and 1970-1979, respectively, for the model calibration and model validation. The results showed that the Nash-Sutcliffe (NS) coefficients and the coefficients of determination $\left(R^{2}\right)$ were $>0.57$ and 0.61 for daily streamflow and 0.70 and 0.74 for monthly streamflow, respectively, demonstrating that the SWAT model can be used in this study.

We analyze the impact of LUCC on streamflow based on the observed LUCC data for 1980 and 2005 . The daily streamflow from 1980 to 2009 was simulated using observed daily meteorological data with the two different sets of land use data. The results showed that two-thirds of the annual streamflow decreased, and the change in the streamflow was different among the different types of land use. Overall, the 30 -year averages of the streamflow decreased on agricultural land but increased in forest areas. To interpret the over- all results, we design five scenarios in this study, including (S1) the present land use for 1980, and the scenarios in which agricultural land was converted into forest: $10 \%$ (S2), $20 \%$ (S3), $40 \%$ (S4), and $100 \%$ (S5). Based on the five scenarios, we use the calibrated and validated SWAT model to analyze the effect of forest construction on the streamflow in detail. The results confirm that the annual streamflow consistently increased with more forest area converted from agricultural land. Interestingly, the rate is almost consistently $7.41 \mathrm{~mm} \mathrm{yr}^{-1}$ per $10 \%$ increase in forest converted from agricultural land. Based on a detailed analysis of each component of streamflow, we found that it was mostly contributed by the baseflow. The overall effect of LUCC on the streamflow in the Wei River basin, the largest branch of the Yellow River, is the result of the balance between the Loess Plateau negative and the earth-rock mountain positive effects. Our results here are not only of great importance in understanding the impact of LUCC on streamflow for a catchment with a very complicated and mixed landscape, but they are also of significance for water resource managing practices.

Data availability. The data used in this paper were obtained from reliable public data repositories. The LUCC and soil data were obtained from the National Science \& Technology Infrastructure of China, the National Earth System Science Data Sharing Infrastructure (http://www.geodata.cn). The DEM data were obtained from the Computer Network Information Center, the Chinese Academy of Sciences (http://srtm.datamirror.csdb.cn/). The meteorological data were obtained from the China Meteorological Data Sharing Service System (http://www.escience.gov.cn/metdata/page/ index.html). The daily streamflow data were from the Ecological Environment Database of the Loess Plateau (http://www.loess.csdb. cn/pdmp/index.action) and the Hydrological Yearbooks of China.

Competing interests. The authors declare that they have no conflict of interest.

Acknowledgements. This research was supported by the following: the National Key Research and Development Program of China (2016YFA0602402); the open research fund of the State Key Laboratory of Desert and Oasis Ecology, Xinjiang, Institute of Ecology and Geography, Chinese Academy of Sciences; the CPSF-CAS Joint Foundation for Excellent Postdoctoral Fellows; the National Key Research and Development Program of China (2016YFC0401401); the influence mechanism and coping strategy of the controlling reservoirs on the hydrological and ecological pattern in the middle and lower reaches of Yangtze River; the Chinese Academy of Sciences (CAS) Pioneer Hundred Talents Program; the International Science and Technology Cooperation Program of China (2014DFA71910); and the Natural Science Foundation of China (41571028, 41601035 and 41401037). We thank the editor and reviewers for their valuable comments that improved the manuscript. 
Edited by: Y. Chen

Reviewed by: B. Narsimlu and two anonymous referees

\section{References}

Abbaspour, K. C.: User manual for SWAT-CUP, SWAT calibration and uncertainty analysis programs, Swiss Federal Institute of Aquatic Science and Technology, Eawag, Duebendorf, Switzerland, 2007.

Allen, M. R. and Ingram, W. J.; Constraints on future changes in climate and the hydrologic cycle, Nature, 419, 224-232, 2002.

Arnold, J., Srinivasan, R., Neitsch, S., George, C., Abbaspour, K., Gassman, P., Hao, F. H., Van Griensven, A., Gosain, A., and Debels, P.: Soil and Water Assessment Tool (SWAT): Global Applications, WASWC, Bangkok, 2009.

Arnold, J. G., Allen, P. M., and Bernhardt, G.: A comprehensive surface-groundwater flow model, J. Hydrol., 142, 47-69, 1993.

Arnold, J. G., Srinivasan, R., Muttiah, R. S., and Williams, J. R.: Large area hydrologic modeling and assessment part I: Model development, J. Am. Water Resour. Assoc., 34, 73-89, 1998.

Beck, H. E., Bruijnzeel, L. A., van Dijk, A. I. J. M., McVicar, T. R., Scatena, F. N., and Schellekens, J.: The impact of forest regeneration on streamflow in 12 mesoscale humid tropical catchments, Hydrol. Earth Syst. Sci., 17, 2613-2635, doi:10.5194/hess-172613-2013, 2013.

Bosch, J. M. and Hewlett, J.: A review of catchment experiments to determine the effect of vegetation changes on water yield and evapotranspiration, J. Hydrol., 55, 3-23, 1982.

Bradshaw, C., Sodhi, N., Peh, K., and Brook, B.: Global evidence that deforestation amplifies flood risk and severity in the developing world, Global Change Biol., 13, 2379-2395, 2007.

Chen, Y., Wang, K., Lin, Y., Shi, W., Song, Y., and He, X.: Balancing green and grain trade, Nat. Geosci., 8, 739-741, 2015.

Deng, L., Liu, G. B., and Shangguan, Z. P.: Land-use conversion and changing soil carbon stocks in China's 'Grain-for-Green' Program: a synthesis, Global Change Biol., 20, 3544-3556, 2013.

Dijk, A. I. J. M. V., Noordwijk, M. V., Calder, I. R., Bruijnzeel, S. L. A., Schellekens, J., and Chappell, N. A.: Forest-flood relation still tenuous - comment on 'Global evidence that deforestation amplifies flood risk and severity in the developing world' by C. J. A. Bradshaw, N. S. Sodi, K. S.-H. Peh and B. W. Brook, Global Change Biol., 15, 110-115, 2009.

Farley, K. A., Jobbágy, E. G., and Jackson, R. B.: Effects of afforestation on water yield: a global synthesis with implications for policy, Global Change Biol., 11, 1565-1576, 2005.

Foley, J. A., Ruth, D., Asner, G. P., Carol, B., Gordon, B., Carpenter, S. R., Stuart, C., Coe, M. T., Daily, G. C., and Gibbs, H. K.: Global consequences of land use, Science, 309, 570-574, 2005.

Gassman, P. W., Reyes, M. R., Green, C. H., and Arnold, J. G.: The soil and water assessment tool: historical development, applications, and future research directions, Center for Agricultural and Rural Development Iowa State University, http://www.card. iastate.edu, http://www.card.iastate.edu (last access: April 2017), 2007.

Hibbert, A. R.: Forest Treatment Effects on Water Yield, Pennsylvania University, Pennsylvania, 527-543, 2001.

Huang, B. W.: Several issues of the impact of forest on environment, China Water Resour., 4, 29-32, 1982.
Huang, Z. G., Ouyang, Z. Y., Li, F. R., Zheng, H., and Wang, X.: Progress in the Effects of Forest Ecosystem on Runoff Based on Forest Catchments, World Forest. Res., 22, 36-41, 2009.

Lacombe, G., Ribolzi, O., de Rouw, A., Pierret, A., Latsachak, K., Silvera, N., Pham Dinh, R., Orange, Lørup, J. K., Refsgaard, J. C., and Mazvimavi, D.: Assessing the effect of land use change on catchment runoff by combined use of statistical tests and hydrological modelling: case studies from Zimbabwe, J. Hydrol., 205, 147-163, 1998.

Lacombe, G., Cappelaere, B., and Leduc, C.: Hydrological impact of water and soil conservation works in the Merguellil catchment of central Tunisia, J. Hydrol., 359, 210-224, 2008.

Lacombe, G., Ribolzi, O., de Rouw, A., Pierret, A., Latsachak, K., Silvera, N., Pham Dinh, R., Orange, D., Janeau, J.-L., Soulileuth, B., Robain, H., Taccoen, A., Sengphaathith, P., Mouche, E., Sengtaheuanghoung, O., Tran Duc, T., and Valentin, C.: Contradictory hydrological impacts of afforestation in the humid tropics evidenced by long-term field monitoring and simulation modelling, Hydrol. Earth Syst. Sci., 20, 2691-2704, doi:10.5194/hess-20-2691-2016, 2016.

Le Maitre, D. C., Scott, D. F., and Colvin, C.: Review of information on interactions between vegetation and groundwater, Water Res. Commiss., 25, 137-152, 1999.

Lenderink, G. and Meijgaard, E. V.; Increase in hourly precipitation extremes beyond expectations from temperature-changes, Nat. Geosci., 1, 511-514, 2008.

Li, P.: The nation has invested a total of more than 4000 billion yuan for the first round of the Grain for Green Project, xinhuanet.com, http://news.xinhuanet.com/politics/2015-08/07/ c_1116185623.htm (last access: April 2017), 2015.

Li, W. H., He, Y. T., and Yang, L. Y.: A summary and perspective of forest vegetation impacts on water yield, J. Nat. Resour., 16, 398-406, 2001.

Li, Y. S.: Effects of forest on water circle on the Loess Plateau, J. Nat. Resour., 16, 427-432, 2001.

Lin, Q. C. and Li, H. E.: Influence and guarantee on ecological basic flow of Weihe River from Baojixia water diversion, J. Arid Land Resour. Environ., 24, 114-119, 2010.

Liu, C. M. and Zhong, J. X.: The influence of forest cover upon annual runoff in the Loess Plateau of China, Acta Geogr. Sin., 33, 112-126, 1978.

Liu, Y. and $\mathrm{Hu}, \mathrm{A}$. Y.: Changes of Precipitation Characters Along Weihe Basin in 50 Years and Its Influence on Water Resources, J. Arid Land Resour. Environ., 20, 85-87, 2006.

Lorup, J. K. and Hansen, E.: Effect of land use on the streamflow in the southwestern highlands of Tanzania, in: International Symposium on Sustainability of Water Resources Under Increasing Uncertainty, at the 5th Scientific Assembly of IAHS, Rabat, Morocco, 1997.

Mango, L. M., Melesse, A. M., McClain, M. E., Gann, D., and Setegn, S. G.: Land use and climate change impacts on the hydrology of the upper Mara River Basin, Kenya: results of a modeling study to support better resource management, Hydrol. Earth Syst. Sci., 15, 2245-2258, doi:10.5194/hess-15-22452011, 2011.

Moriasi, D. N., Arnold, J. G., Van Liew, M. W., Bingner, R. L., Harmel, R. D., and Veith, T. L.: Model evaluation guidelines for systematic quantification of accuracy in watershed simulations, T. ASABE, 50, 885-900, 2007. 
Nash, J. and Sutcliffe, J. V.: River flow forecasting through conceptual models part I - A discussion of principles, J. Hydrol., 10, 282-290, 1970.

NDRC: National Development and Reform Commission spokesperson answer to reporters' request on launching a new round of Green for Grain, xinhuanet.com, http: //news.xinhuanet.com/politics/2014-09/27/c_1112652394.htm (last access: April 2017), 2014.

Neitsch, S. L., Arnold, J. G., Kiniry, J. R., and Williams, J. R.: Soil and Water Assessment Tool (SWAT) Theoretical Documentation: Version 2000, Texas Water Resources Institute Technical Report No. 406, Texas Water Resources Institute, Texas, 2011.

Ogden, F. L., Crouch, T. D., Stallard, R. F., and Hall, J. S.: Effect of land cover and use on dry season river runoff, runoff efficiency, and peak storm runoff in the seasonal tropics of Central Panama, Water Resour. Res., 49, 8443-8462, 2013.

Pall, P., Allen, M. R., and Stone, D. A.; Testing the ClausiusClapeyron constraint on changes in extreme precipitation under $\mathrm{CO}_{2}$ warming, Clim. Dynam., 28, 351-363, 2007.

Price, K.: Effects of watershed topography, soils, land use, and climate on baseflow hydrology in humid regions: A review, Prog. Pys. Geogr., 35, 465-492, 2011.

Shao, H.: Simulation of Soil and Water Loss Variation toward Terrace Practice in the Weihe River Basin, Doctor, Northwest A \& F University, Yangling Shaanx, 2013.

Shao, H., Baffaut, C., and Gao, J. E.: A Process-Based Method for Evaluating Terrace Runoff and Sediment Yield, Paper No. 121341006, Conference Paper, 29 July-1 August 2012, Dallas, Texas, doi:10.13031/2013.42034, 2012.

Shao, H., Baffaut, C., Gao, J. E., Nelson, N. O., Janssen, K. A., Pierzynski, G. M., and Barnes, P. L.: Development and application of algorithms for simulating terraces within SWAT, T. ASABE, 56, 1715-1730, 2013.

Smith, R. and Scott, D.: The effects of afforestation on low flows in various regions of South Africa, Water S.A., 18, 185-194, 1992.

Sriwongsitanon, N. and Taesombat, W.: Effects of land cover on runoff coefficient, J. Hydrol., 410, 226-238, 2011.

Tian, J. L.: Environmental effects of Loess Plateau Ecological Construction, China Meteorological Press, Beijing, 2010.

Tobella, A. B., Reese, H., Almaw, A., Bayala, J., Malmer, A., Laudon, H., and Ilstedt, U.: The effect of trees on preferential flow and soil infiltrability in an agroforestry parkland in semiarid Burkina Faso, Water Resour. Res., 50, 3342-3354, 2014

Van Liew, M. W. and Garbrecht, J.: Hydrologic simulation of the Little Washita River experimental watershed using SWAT, J. Am. Water Resour. Assoc., 39, 413-426, 2003.

VanShaar, J. R., Haddeland, I., and Lettenmaier, D. P.: Effects of land-changes on the hydrological response of interior Columbia River basin forested catchments, Hydrol. Process., 16, 24992520, 2002.

Wagner, P. D., Kumar, S., and Schneider, K.: An assessment of land use change impacts on the water resources of the Mula and Mutha Rivers catchment upstream of Pune, India, Hydrol. Earth Syst. Sci., 17, 2233-2246, doi:10.5194/hess-17-22332013, 2013.

Wang, F.: Study of runoff and value of ecosystem based on landuse change in Weihe River basin, Master, Northwest A \& F University, Yangling Shaanxi, 2013.
Wang, H.: The Effects of Typical Measures of Soil and Water Conservation on Ecological Basic Flow Recharged from Groundwater, Doctor, University of Chinese Academy of Sciences, Beijing, China, 2014.

Wang, L. X.: Effect of construction and protective of vegetation on protection and utilization of water resources, Xiangshan Conference, Beijing, 2000.

Wang, Y. H., Yu, P. T., Feger, K. H., Wei, X. H., Sun, G., Bonell, M., Xiong, W., Zhang, S. L., and Xu, L. H.: Annual runoff and evapotranspiration of forestlands and non-forestlands in selected basins of the Loess Plateau of China, Ecohydrology, 4, 277-287, 2011.

Wang, Y., Shao, M., and Shao, H.: A preliminary investigation of the dynamic characteristics of dried soil layers on the Loess Plateau of China, J. Hydrol., 381, 9-17, 2010a.

Wang, Y., Shao, M., and Liu, Z.: Large-scale spatial variability of dried soil layers and related factors across the entire Loess Plateau of China, Geoderma, 159, 99-108, 2010b.

Westra, S., Fowler, H. J., Evans, J. P., Alexander, L. V., Berg, P., Johnson, F., Kendon, E. J., Lenderink, G., and Roberts, N. M.; Future changes to the intensity and frequency of short-extreme rainfall, Rev. Geophys., 52, 522-555, 2014.

Woodward, C., Shulmeister, J., Larsen, J., Jacobsen, G. E., and Zawadzki, A.: Landscape hydrology. The hydrological legacy of deforestation on global wetlands, Science, 346, 844-847, 2014.

Xu, Y. D., Fu, B. J., and He, C. S.: Assessing the hydrological effect of the check dams in the Loess Plateau, China, by model simulations, Hydrol. Earth Syst. Sci., 17, 2185-2193, doi:10.5194/hess17-2185-2013, 2013.

Yan, Y., Tian, J., Fan, M. S., Zhang, F. S., Li, X. L., Christie, P., Chen, H. Q., Lee, J., Kuzyakov, Y., and Six, J.: Soil organic carbon and total nitrogen in intensively managed arable soils, Agriculture, Ecosyst. Environ., 150, 102-110, 2012.

Yin, J., He, F., Xiong, Y. J., and Qiu, G. Y.: Effects of land use/land cover and climate changes on surface runoff in a semi-humid and semi-arid transition zone in northwest China, Hydrol. Earth Syst. Sci., 21, 183-196, doi:10.5194/hess-21-183-2017, 2017.

Zhang, H. and Hiscock, K.: Modelling the impact of forest cover on groundwater resources: A case study of the Sherwood Sandstone aquifer in the East Midlands, UK, J. Hydrol., 392, 136-149, 2010.

Zhang, T. Z.: Based on hydrological characteristics of Donggou and Xigou catchment in Yongding River to analyze the hydrological function of forest vegetation, Resour. Sci., 6, 90-98, 1984.

Zhang, Y. X.: The research of watershed runoff and sediments variation toward to the soil and water conservation terrace measure, Doctor, Northwest A \& F University, Yangling Shaanxi, 2014.

Zhang, Y. X., Gao, J. E., and Shao, H.: The Terraced Fields Environmental Impact Assessment in Data-Scarce Areas Based on the Embedded Terraced Module SWAT Model, Nat. Environ. Poll. Technol., 13, 283-288, 2014.

Zuo, D., Xu, Z., Zhao, J., Abbaspour, K. C., and Yang, H.: Response of runoff to climate change in the wei river basin, china, Hydrological Sciences Journal/journal Des Sciences Hydrologiques, 60, 1-15, 2015. 